\title{
Citation Indexing Revisited: Garfield's Early Vision and Its Implications for the Future
}

\author{
Henry Small* \\ SciTech Strategies, Inc., Albuquerque, NM, United States
}

Eugene Garfield's ideas on citation indexing were gradually shaped over the course of the 1950s by his exposure to the thinking of various individuals such as J. D. Bernal, H. G. Wells, Chauncey Leake, William Adair, and Joshua Lederberg. Two key concepts emerged during this early period which guided his later work: the importance of interdisciplinary or cross-disciplinary research and the notion that references could be used to index the documents they cited. These ideas were the basis for his landmark product the Science Citation Index. However, it took many years for the significance of his early insights to be appreciated and manifested in research studies and products. And in a real sense, we continue to work out the implications of these ideas even today.

Keywords: citation indexing, +interdisciplinary research, citation contexts, mapping science, Eugene Garfield history

\section{INTRODUCTION}

Gene Garfield's views on the nature of science ultimately led him to create a unified citation index

OPEN ACCESS

Edited by:

David A. Pendlebury, Clarivate Analytics, United States

Reviewed by: Ying Ding, Indiana University Bloomington, United States

Juan Ignacio Gorraiz, University of Vienna, Austria

*Correspondence: Henry Small hsmall@mapofscience.com

Received: 13 December 2017 Accepted: 12 February 2018

Published: 02 March 2018

Citation:

Small H (2018) Citation Indexing Revisited: Garfield's Early Vision and Its Implications for the Future.

Front. Res. Metr. Anal. 3:8. doi: 10.3389/frma.2018.00008 for all of science rather than separate indexes covering individual disciplines. Disciplinary indexing services such as Chemical Abstracts and Biological Abstracts were the rule in the 1950s and 1960s. It was not initially clear that a unified approach would be commercially viable compared to separate disciplinary indexes, but he took the gamble. However, whether the unified index captured interdisciplinary activity was not evident until much later when various analytical methods provided a global view of the data.

His views on citation indexing evolved gradually from the point in 1953 when he first learned about how citation indexing had been applied in the field of law to the actual compilation of the first Science Citation Index (SCI) for 1961, particularly regarding the amount and type of information that should be captured. In his early work, he had speculated on what could be done if the sentences at the point of citation could be captured and analyzed. However, the practical limitations of production forced him to modify this ambitious plan. Reviewing these original plans helps us envision how we need to think about citation indexing today.

My goal in this paper is to show how Gene's conception of a multidisciplinary citation index can be combined with his early ideas on citation indexing, and how combining these ideas opens up new research possibilities.

\section{HYBRID DISCIPLINES AND THE STRUCTURE OF SCIENCE}

Prior to his going off to college, Gene was given a copy of J. D. Bernal's book the Social Function of Science by one of his Marxist-leaning uncles (Bernal, 1939; Garfield, 2007, p. 41). Gene took the book to college in Colorado in 1942 at age 17 and discussed it with his fellow students. Bernal's views on 
science were, of course, highly influenced by Marxist ideology, which was popular in New York City in the 1930s where Gene grew up. For example, Bernal wrote in 1938: "The corner-stone of the Marxist state is the utilization of human knowledge, science and technique, directly for human welfare" (Bernal, 1939, p. 222). In later life, Gene seems to have shared at least one aspect of that ideology, namely that science should serve human welfare (Garfield, 2007, p. 82), although there is no evidence that Gene, as a businessman and owner of Institute for Scientific Information (ISI), shared Bernal's political views that science was better suited to the communist than the capitalist system. Bernal thought the communist system could better plan and coordinate the work of scientists.

For such planning purposes, Bernal proposed a “... general framework or skeleton of organization which would remain substantially unchanged for a time longer than it is convenient to plan for" (Bernal, 1939, p. 279). He then presented what might be regarded as an early map of science.

Figure 1 shows only the physical science portion of this map. The biology portion is on a separate page, with arrows going from one page to the other indicating the flow of knowledge. What
Bernal calls "sophisticated" (basic) science is at the top and "practical" (or applied) science at the bottom with arrows connecting top and bottom as well. Bernal went on: "Such a chart must not be taken as an adequately considered scheme, which whole committees of experts would be needed to prepare ..." (Bernal, 1939 , p. 280). We do not know whether Gene was influenced by Bernal's maps to undertake later forays into science mapping and the development of the "historiograph," but given that he had studied Bernal's book at an early age, a formative influence is quite possible.

In his college and early working career, Gene was exposed to many different scientific disciplines and disciplinary combinations: chemistry, medicine, physics, engineering, and hybrid fields such as physical chemistry when he worked for Louis P. Hammett at Columbia University after receiving his undergraduate degree in chemistry. At different points in his college career, he wanted to be a biochemist or go to medical school (Garfield, 2007, p. 14).

In 1952 at age 27, he took his first purely information job at the Welch Medical Library in Baltimore to index chemical nomenclature in medical articles (Garfield, 2007, p. 18). He had been introduced to the field of chemical information by the

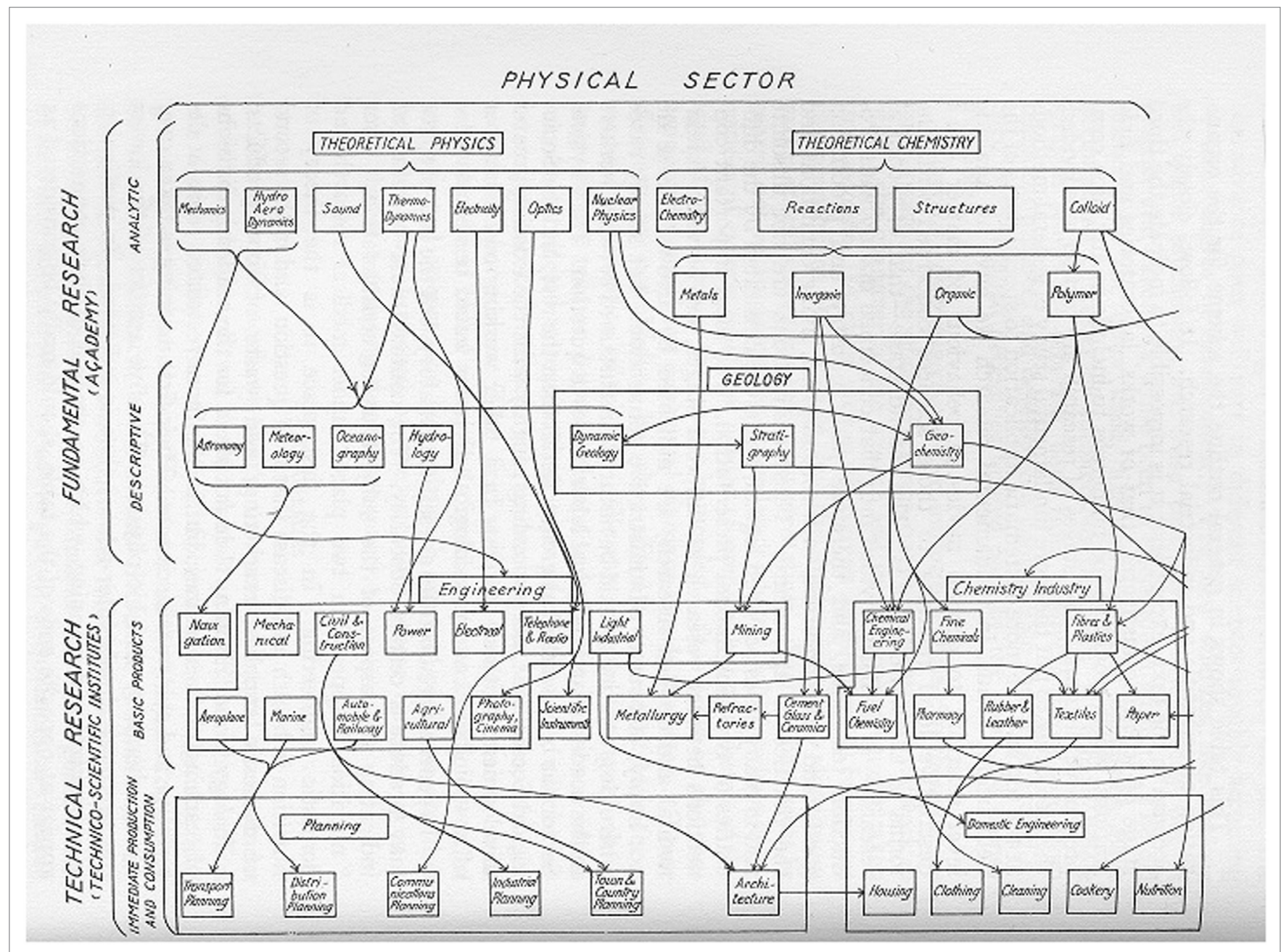

FIGURE 1 | Bernal's map of the physical sciences. Reprinted from Bernal (1939) (p. 281), with permission of MIT Press. 
MIT chemist James Perry whom Gene had met at an American Chemical Society (ACS) meeting in New York City. The Welch Medical Library, which is part of the Johns Hopkins School of Medicine, was engaged in a project sponsored by the Army Medical Library to develop an indexing system for the medical literature. The system of medical subject headings developed on that project would later be adopted by the National Library of Medicine. This project, under the direction of Sanford Larkey, library director, and medical historian, was at the cutting edge of the field then known as documentation.

On that project, Gene was exposed to many new ideas in documentation. For example, he became, in his own words, a "punch card guru" and an expert in programming the newly arrived IBM 101 statistical machine (Garfield, 2007, p. 43). It was his experience on this project that lay the groundwork for many of his future endeavors and products including Current Contents, the SCI, and a science newspaper. At a meeting of the Maryland chapter of the ACS in 1952, Gene addressed "The crisis in Chemical Literature." In his unpublished paper, we can see him already focusing on bibliographic references, and in particular, cross references: "If authors would provide the CA abstract number with each bibliographical citation I can assure you that CA abstracts in the future would be much more informative by providing cross references to related abstracts" (Garfield, 1952a). He knew this first hand, because he was a volunteer indexer for Chemical Abstracts.

On the Welch project, he also began thinking about access to the totality of human knowledge. In another unpublished paper, Gene wrote: "The Renaissance man could attempt to master all of human knowledge in a lifetime, but certainly 20th century man cannot even conceive of doing this in one hundred lifetimes. But if he cannot know everything, we can be satisfied with the ability to recall any small portion of the totality of knowledge at any given moment. Surely Faustus would have liked to have at his fingertips the record of all previous human achievements, if he could simply reach down and consult his universal pocket encyclopedia ... We documentalists envision an eighth wonder of the world: a mechanical brain that will recall any or all of the world's wisdom at will" (Garfield, 1953). In the same essay, he made an early mention of H. G. Wells' world brain (Wells, 1938).

In the introduction to the first SCI in 1963, Gene wrote the following somewhat cryptic line, recalling his work at the Welch library: "I had been working out a method of utilizing the sentences and citations appearing in review articles as entries in large-scale interdisciplinary science indexes" (Garfield, 1963). He then referenced an unpublished paper from 1952 that he wrote while working on the Welch project entitled "Review Literature as a Source of Critical Entries for Scientific Indexes" (Garfield, 1952b). Gene has stated in oral history interviews that it was Chauncey Leake who encouraged him to study why review articles were so important to scientists (Garfield, 2007, p. 25). Leake was a pharmacologist and medical historian who was the chair of the advisory committee for the Welch project. After studying review articles, Gene concluded that almost every sentence of a review was like an indexing statement for the reference it cited (Thackray and Brock, 2000). This insight into the connection between indexing and references in papers no doubt helped lead
Gene to his breakthrough idea, the SCI. However, the path would be a circuitous one, fraught with uncertainty, and would not end up as he had originally envisioned.

The story of how he got the idea to create a citation index for science has been recounted many times (Wouters, 1999, p. 23). On the Welch project, he organized a conference on machine methods in documentation in which 300 people attended, including some of the leading figures in documentation of the day. The keynote speaker at the conference was a vice president of Johns Hopkins who was quoted as saying "Man was going to drown in a flood of papers" (Thackray and Brock, 2000, p. 16). This statement was picked up by the wire services and reached William Adair in Colorado, the retired president of Shepard's Citations, the so-called legal citator, which was started back in the nineteenth century, and showed lawyers where earlier court decisions were cited, overturned, or sustained. Adair wrote to the project and Larkey told Gene to write back. It turned out Adair had suggested, back in the 1920s, that citation indexes might be a good way to index science and engineering. Gene went to look at the legal citator in the Baltimore Public Library and suggested to Adair that he write a paper about how the concept could be applied to science.

Later on, after he was fired from the Welch project and decided to attend library school at Columbia University, Gene wrote a term paper on citation indexing (Garfield, 2007, p. 24). This evolved into his 1955 paper "Citation indexes for science" which was published in Science with the help of Bentley Glass, a geneticist whom he had met at the Welch project (Garfield, 1955). Gene saw this as "an association-of-ideas index" in which a citing author could associate his or her idea with any earlier idea whether inside or outside the author's field. Gene speculated that such indexes would be used both for retrieval of follow-up papers and as a measure of the "impact" of papers. This dual function-retrieval and assessment-preoccupied Gene for most of his career.

In the 1955 paper, he also alluded to his work at the Welch project: "By using authors' references for the Citation Index we are in effect utilizing an actual army of indexers, in that every time an author makes a reference he is essentially indexing that work from his own point of view. It can be shown that this is especially true in the review article where each statement, followed by a reference, is very much like an index entry ...." This was followed by a citation to his unpublished paper from 1952 (Garfield, 1952b).

The Science paper also argued that citation indexing would capture interdisciplinarity: "The farther away you get from the immediate subject area of the main article, the fewer the references to it you will locate. Yet these may well be the most useful references of all, for the cross fertilization of subject fields is one of the most important problems in scientific literature" (Garfield, 1955). Cross-fertilization, Gene thought, is where new hybrid fields are born.

Four years later in 1959, when he had completed his library degree and began his consulting business in Philadelphia, he presented a paper on the idea of a "unified index to science" at the International Conference on Scientific Information held in Washington, DC, USA. This was an important conference for Gene where he met researchers from all over the world, including J. D. Bernal. Gene's paper at the conference dealt with the 
idea of combining all existing disciplinary indexing services, and he noted some of the hybrid disciplines that might benefit from a unified approach and which he considered key to the advancement of science: "A Unified index to Science would be a convenience even if the strictly academic intra-disciplinary approaches were still the primary targets of today's research. In this era, however, of the bio-physicist, the psycho-chemist, the human engineer, the instrumentation scientist, and the cosmobiologist, a unified Index to Science is an absolutely necessary working tool for unfettered scientific progress" (Garfield, 1959). Shortly thereafter, this concept of a unified subject index would give way to the bolder idea of a unified citation index.

\section{EARLY IDEAS FOR A CITATION INDEX FOR SCIENCE}

Joshua Lederberg, who had received a Nobel Prize in 1958, read Gene's 1955 article in Science and was intrigued. He scribbled a note to Gene in 1959 asking what had happened to the idea. Lederberg wrote: "In the nature of my work, I have to spend a fair amount of effort in reading the literature of collateral fields and it is infuriating how often I have been stumped in trying to update a topic, where your scheme would have been just the solution" (Lederberg, 2000, p. 39). Gene replied that, in fact, he had been trying to get funding for the project from the U.S. National Science Foundation but without success, one reason being that he was a businessman, not sponsored by an academic organization. With typical brashness, he claimed "... with one tenth the budget of Chemical Abstracts I could probably put out a citation index for all of science - and once begun the enterprise would probably be self-supporting." Going out further on a limb he predicted: ... "I have great faith that the citation index will one day be a spur to many new scientific discoveries ..." (Lederberg, 2000, p. 42). Lederberg suggested he submit a proposal to the genetics study section at the U.S. National Institutes of Health (NIH). This strategy was eventually successful and work began on compiling a citation index for 1961 and a subset genetics citation index. The indexes were published in 1964.

The exchange of letters between Lederberg and Garfield in 1959 shows the evolution of Gene's concept of citation indexing starting with ideas developed in the Welch project regarding the citing sentence level of citation indexing. In a letter dated July 14,1959 , we get a glimpse of this early thinking. Lederberg had sent Gene a packet of his papers where Lederberg had marked within the texts where review articles had been cited. Gene wrote to Lederberg: "There is also a distressing reminder in your papers how difficult it can be to trace the statement made in connection with a particular citation. For example, you cite Cummins in your paper but without the use of numbers to identify your citation it is quite a chore to locate the sentence involved" (Lederberg, 2000 , p. 55). Gene thought there was something very useful about what Lederberg had said about the Cummins article for readers of that article and that this information should be made accessible through the citation index. Gene phrased this as the "topic definition of content of a paper," which was what he was getting at in his unpublished study (Garfield, 1952b). Today we might rephrase this to say that the aggregate of citing statements for a given cited paper defines its content and meaning for the community.

In a follow-on letter from September 9, 1959, Gene elaborated on his concern to provide as much information as possible on the location and content of the citing passage. He had been discussing this concept with people from various government agencies. $\mathrm{He}$ told Lederberg: "We also discussed the question of specifying the 'kind' of citation involved. I believe that citation index research will pay off handsomely in the future in that this research will characterize all the different ways in which people 'cite' the earlier literature" (Lederberg, 2000, p. 57). For example, in his project, he could characterize each citation as a review, communication, editorial, errata, translation, abstract, book, discussion, summary, bibliography, or book review. He could also attempt to discern whether the citation was a refutation or a confirmation, or a citation to a method or a material. Perhaps identifying the section of the paper, the citation came from could be useful, whether experimental, theoretical, or introductory. And, of course, identifying the page number on which the citation is made would "speed up locating the pertinent statements." The statements he is referring to here are the citing sentences which could indicate the content of the cited paper. Lederberg, for his part, vigorously pushed back against these qualified approaches and strongly urged Gene to pursue the original plan of a complete citation index for a set of major journals. Lederberg voiced his objection to the more intellectually difficult approaches like coding citations by function and recommended just capturing the citing and cited identifiers. Lederberg wrote: "This comment may reflect my own bias that the citation index at present needs no research to be an extremely useful tool, its uses including functional analysis of literature citations" (Lederberg, 2000, p. 62).

We can speculate on what might have happened to the citation index concept if Gene had adopted some of his more complicated ideas on indexing described in his letters to Lederberg, such as coding reference locations in the text of papers or their rhetorical function. Adopting such refinements would have dramatically increased the time and cost of production and probably brought the whole project to a grinding halt. In the inaugural edition of the citation index for 1961 and all subsequent editions, there was no indicator for the location of the citation within the citing text, citing items only being identified by their starting page number. This simplification allowed the scaling up of production via clerical data entry and avoided the need to hire professional indexers.

In later years, of course, a major research topic has emerged dealing with the nature of citations and the reasons for citing, generally referred to as citation context analysis (Moravcsik and Murugesan, 1975; Small, 1982). Nowadays, with the extensive availability of full text in xml format, Gene's original vision of citation indexing augmented by content analysis looks more and more feasible. In later writings, he seems aware of the possibility. In a 1999 tribute to the late Fred Kochen, he wrote: "It is already possible to use citation links ... to go back and forth from indexes to full-text journals" (Garfield, 1999).

Two further pieces of evidence point to Gene's interest in making citing passages available for further analysis. Around the time he began working on the Welsh project, Gene had the idea 
of creating a device that he called the "copywriter," a handheld device for capturing an image of a string of text by moving a stylus across a line of printed text (Garfield, 1973). After leaving the project, Gene continued to pursue this idea, eventually producing a prototype and applying for a patent. We do not know what circumstance prompted him to conceive of such a device so early in his career. He claimed later on that it was to ease the task of notetaking, but it is not implausible that one of the applications he had in mind was the copying of citing passages from scientific papers.

Many years later in 1997, Gene and I wrote a letter to the editor of the Journal of the American Society for Information Science and Technology protesting the adoption of the APA author-year format for references rather than the numbered format used up to that time and prevalent in natural science journals. We stated: "... the numbered reference list is important to citation analysis and retrieval since it facilitates location of the sentence or paragraph in which the citing statement occurs. Almost daily we track the contextual environment of citations using their numbered locations in text" (Garfield and Small, 1997). Of course, on this issue, we were on the wrong side of history, but the letter illustrates Gene's interest in this type of analysis, which went back to the very beginning of his career.

\section{CREATING THE INTERDISCIPLINARY CITATION INDEX}

In the Garfield-Lederberg correspondence from 1959, Gene also floated the idea of creating separate citation indexes for disciplinary journal subsets or individual journals, worrying that a multidisciplinary index would be more difficult to market. Lederberg objected to this idea as well: "I feel that a good general citation index will be of greater value to genetics than a too specialized run that sticks too closely to the discipline" (Lederberg, 2000, p. 63).

Gene did end up creating at least one disciplinary index, the Genetics Citation Index, constructing it, however, as a subset of the multidisciplinary citation index for 1961. Lederberg had urged Gene to include, in the genetics index, literature from other disciplines that were pertinent to genetics and the only way to do this was by starting with the broader multidisciplinary index. In Lederberg's introduction to the Genetics Citation Index, he states: "For many reasons genetics is an especially apt field for the introduction of citation indexing. It is inherently interdisciplinary, cutting across biochemistry, statistics, agriculture, and medicine, so that geneticists need insight into a wide range of scientific literature" (Lederberg, 1964). To create the genetics subset of the 1961 index, however, turned out to be a very complex process involving matching lists of independently compiled genetics authors and journals against the citing and cited data records of the citation index. Clearly, it was easier to produce a unified index than extract a disciplinary subset that included interdisciplinary links.

In Gene's introduction to the 1961 citation index, he states his rationale for not creating separate disciplinary indices, returning to his original views regarding the need for a unified, multidisciplinary index: "The increasing interdisciplinary trend of science indicates that categorical citation indexes would indeed only be a temporary or partial solution to the problem" (Garfield, 1963). In other words, Gene saw the future of science as an interdisciplinary endeavor. Lederberg suggested that the index be called the SCI and Gene proudly proclaimed that his index is "probably the largest single international-inter-disciplinary index to the literature of science ever compiled." As precedent, we might point to the Royal Society's International Catalogue of Scientific Literature and the earlier Catalogue of Scientific Papers 1800-1900 (Csiszar, 2017).

As it turned out, however, it did not prove easy to commercialize the unified index concept (Garfield, 2007, p. 34). In the end, Garfield brought in outside investors to keep it going when the revenues from Current Contents were not enough to support the effort, but the $S C I$ eventually did become self-supporting. Meanwhile various experiments were conducted, notably the idea of the "historiograph," based on a suggestion from the NIH researcher Gordon Allen (Wouters, 1999, p. 53), showing the evolution of a research area using direct citation links, which much later on led to the HistCite software (Garfield et al., 2003). I think it is fair to say, however, that by the late 1960s the promise of the cross-fertilization held out by the unified index concept had not yet been fully realized.

\section{THE SCI AND THE STUDY OF INTERDISCIPLINARITY}

While Gene's early conviction on how citation indexing would foster the hybridization and cross-fertilization of scientific fields was critical to the design and implementation of the SCI, there had been no systematic demonstration of this capability. The "historiograph" study had dealt with citation links within a single field, the genetic code (Garfield et al., 1964), and even his Automatic Subject Citation Alert product which was capable of retrieving literature on a weekly basis from multiple fields based on a user-defined profile could not systematically reveal crossdisciplinary research (Garfield and Sher, 1967).

Around 1970, however, an important step toward exploring this phenomenon was taken in the development of the journal citation index or what came to be called the Journal Citation Reports (JCR) (Garfield, 1972). This aggregation of citation patterns at the journal level allowed researchers to quantify the frequency of citation across disciplinary boundaries when disciplines were defined as individual journals or groups of journals. Studies were undertaken to map the citation flows between journals or disciplines using JCR data. These data were also used to expand the $S C I$ journal coverage and create new citation indexes.

In 1974, I was involved in devising another method of aggregation of citation data, not based on journals but on a clustering of highly cited papers using co-citation. This led to the creation of a spatial mapping of papers, specialties, and disciplines, that is, a mapping of science (Marschakova, 1973; Small, 1973). Before coming to ISI, my work at the American Institute of Physics on a history of science project at the Niels Bohr Library in New York City had convinced me that historians needed the ability to map disciplines, including the ability to drill down to the level of specific discoveries. Obviously this required a machine-readable 
database with wide coverage of the scientific literature. I wrote to all the database producers and services at the time, but most were single discipline based. Only ISI responded to my inquiry.

When I began my research at ISI in 1972, it was not clear if I would be able to show interdisciplinary structure. Thumbing through the pages of the SCI, I ran across a highly cited paper in particle physics that I had heard about. I wondered if there were other papers on the topic. I quickly found a couple and to my surprise when I compared the lists of citing papers, they were many in common. I had attempted a similar approach in my project at the Niels Bohr Library using a sampling of references for each paper with, however, limited success (Small, 2003). My results using the $S C I$, with much more comprehensive data, provided initial evidence of the existence of strong co-citation links. With the help of some data processing people at ISI and collaborators at Drexel University, we quickly developed software to automatically find such links, and it turned out they formed clusters in specific topics in physics, chemistry, and biology (Small and Griffith, 1974).

The basic idea behind co-citation mapping was to sample highly cited papers across the full index under the assumption that they could be used as intellectual markers, much in the vein of Kuhn's exemplars. The highly cited papers, defined by some threshold, provided a convenient sampling frame. I began collaborating with Belver Griffith at Drexel University and on weekends, he would go sailing on the Chesapeake Bay. On one such weekend, on a call over a ship-to-shore radio, we discussed how, if we could define a co-citation relationship between specialty clusters, we might be able to aggregate them into something like disciplines, and then study the linkages between them. Much to our surprise, this worked and resulted in our first interdisciplinary map in 1974 (Griffith et al., 1974). Scaling up this first experiment led to a map that appeared in a Science news article by Nicolas Wade in 1975 (Figure 2) (Wade, 1975) and other similar maps.

\section{COMBINING INTERDISCIPLINARY MAPPING WITH CITATION CONTEXTS}

Finding interdisciplinary links was an exciting development but it raised further questions, such as what did the links mean? Because each reference could be attached to a passage in the paper

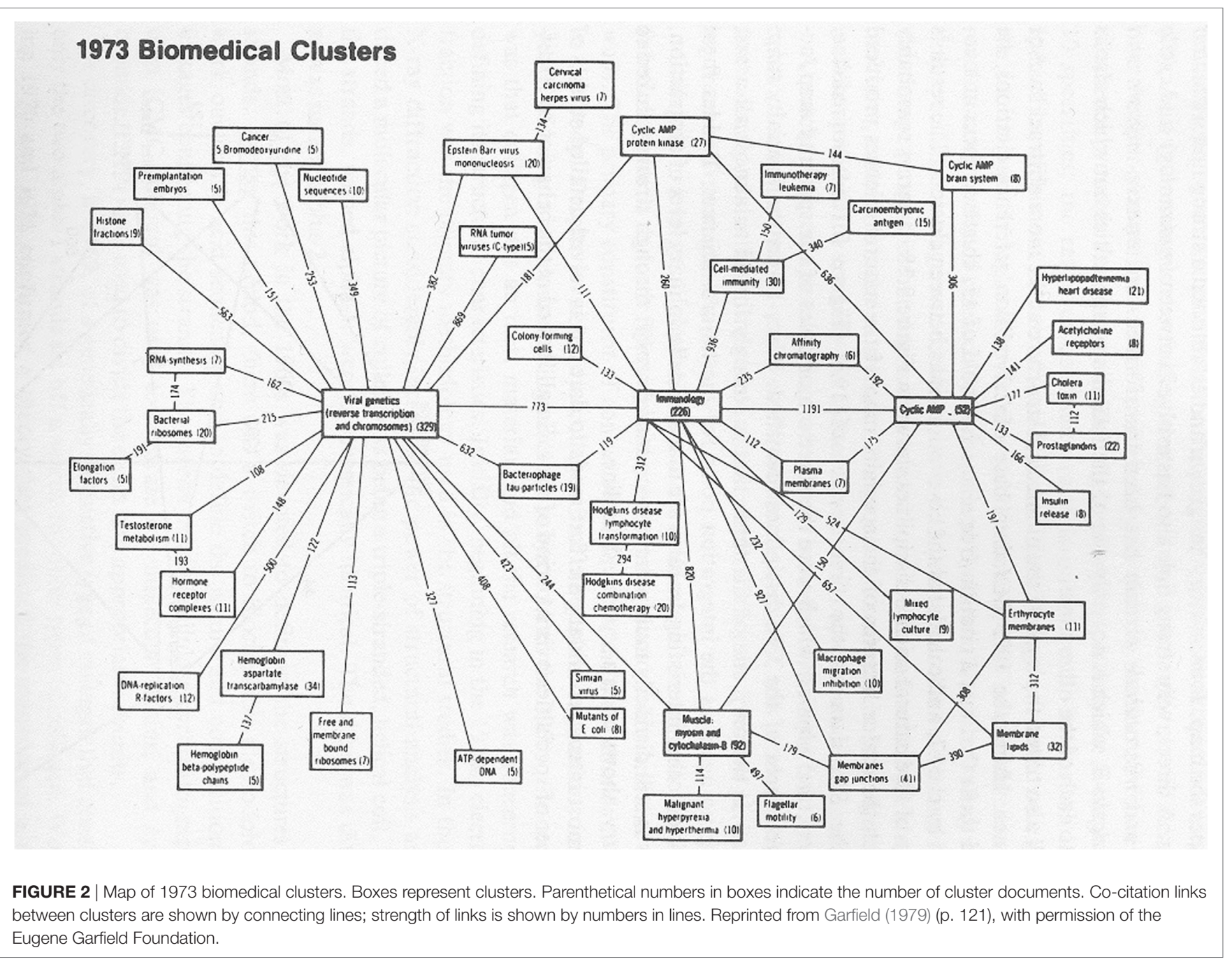


that had cited it, the nature of the interdisciplinary co-citations could, in principle, be studied at the level of text. At the time, I was not familiar with Gene's earlier ideas on using citing sentences as inspired by Chauncey Leake. In addition, in the 1970s, access to full text of articles was essentially non-existent, so the data had to be compiled by hand.

Later on, I was able to investigate the nature of some of these interdisciplinary links using co-citation contexts, that is, passages in which an author cites documents in two clusters that span disciplines. I found that some of these links were based on scientists' thinking by analogy about problems in different fields (Small, 2010). These analogies could act as bridges between different disciplines. In other cases, methods or ideas were being imported from one discipline to another. It was the sum of these connections and exchanges that gave unity to science, and made it possible to navigate from one end of science to another, from psychology to astrophysics, through many intermediate research fields (Small, 1999).

\section{CONCLUSION}

Of course, much work remains to be done to explore the various types of interdisciplinary relationships. Only now do we find ourselves with access to a sufficient corpus of full text to undertake the necessary experiments.

I see this effort now as an amalgamation of two of Gene's primordial ideas: the idea of a unified, multidisciplinary citation index, and the importance of citing passages in understanding

\section{REFERENCES}

Bernal, J. D. (1939). The Social Function of Science. London, UK: Routledge \& Kegan Paul Ltd. Reprinted by MIT Press in 1967.

Chen, C., and Song, M. (2018). Representing Scientific Knowledge: The Role of Uncertainty. London, UK: Springer.

Csiszar, A. (2017). The catalogue that made metrics and changed science. Nature 551, 163-165. doi:10.1038/551163a

Garfield, E. (1952a). The Crisis in Chemical Literature. Unpublished Paper. Available at: http://www.garfield.library.upenn.edu/papers/crisisinchemlit1952.html

Garfield, E. (1952b). Review Literature as a Source of Critical Entries for Scientific Indexes. Eugene Garfield Papers at the Chemical Heritage Foundation, Philadelphia, PA.

Garfield, E. (1953). Librarian versus Documentalist. Unpublished Paper. Available at: http://www.garfield.library.upenn.edu/papers/librarianvsdocumentalisty1953.html

Garfield, E. (1955). Citation indexes for science: a new dimension in documentation through association of ideas. Science 122, 108-111. doi:10.1126/ science.122.3159.108

Garfield, E. (1959). "A unified index to science," in Proceedings of the International Conference on Scientific Information 1958, Vol. 1 (Washington, DC: National Academy of Sciences - National Research Council), 461-474. Available at: http://garfield.library.upenn.edu/essays/v2p674y1974-76.pdf

Garfield, E. (1963). "Introduction to the science citation index," in Science Citation Index, Vol. 1, v-xvi. Available at: http://garfield.library.upenn.edu/papers/80.pdf

Garfield, E. (1972). Citation analysis as a tool in journal evaluation. Science 178, 471-479. doi:10.1126/science.178.4060.471

Garfield, E. (1973). "Introducing the copywriter and ISI's subsidiary, Selective Information Devices, Inc. (SID)," in Essays of an Information Scientist, Vol. 1, 438-441. Available at: http://garfield.library.upenn.edu/essays/ V1p438y1962-73.pdf

Garfield, E. (1979). Citation Indexing: Its Theory and Application in Science, Technology and Humanities. Philadelphia: ISI Press. the nature of citation links. The ultimate goal of such research is making the concepts and methods in various disciplines accessible to other disciplines, which would be the realization of Gene's cross-fertilization of fields.

Some of the remaining tasks have to do with the linguistic analysis of the textual passages associated with these links. Various methods are available to delineate specialties and disciplines using citation-based metrics such as co-citation or direct citation (Klavans and Boyack, 2017). Equally challenging is the information summarization on the citing or co-citing passages, and the computation of the degree of similarity or consensus among them. Finally, and most ambitiously, we need the ability to classify by citation function, and to gauge what Chen calls the meta-knowledge content (Chen and Song, 2018), including the level of uncertainty and other sentiments regarding the knowledge that is shared. From the early studies I have seen, it appears that $\mathrm{AI}$ and machine learning techniques can be applied to help us arrive at such a categorization by citation function (Teufel et al., 2006).

It is my hope that Gene's early vision of what citation indexing can tell us about the nature of interdisciplinary research will soon come to fruition.

\section{AUTHOR CONTRIBUTIONS}

The author confirms being the sole contributor of this work and approved it for publication.

Garfield, E. (1999). "From the world brain to the informatorium ...with a little help from Manfred Kochen," in Paper Presented at the University of Michigan, Ann Arbor, Symposium in Honor of Manfred Kochen. Available at: http://garfield. library.upenn.edu/papers/kochen_worldbrain.html

Garfield, E. (2007). "Eugene Garfield: life story (video)," in Web of Stories. Available at: https://webofstories.com/play/eugene.garfield/1

Garfield, E., Pudovkin, A. I., and Istomin, V. I. (2003). Mapping the output of topical searches in the web of knowledge and the case of Watson-Crick. Inf. Technol. Libr. 22, 183-187.

Garfield, E., and Sher, I. H. (1967). ASCA (Automatic Subject Citation Alert): a new personalized current awareness service for scientists. Am. Behav. Sci. 10, 29-32. doi:10.1177/000276426701000507

Garfield, E., Sher, I. H., and Torpie, R. J. (1964). The Use of Citation Data in Writing the History of Science. Philadelphia, PA: Institute for Scientific Information. Available at: http://www.garfield.library.upenn.edu/papers/useofcitdatawritinghistofsci.pdf

Garfield, E., and Small, H. (1997). Citation format. J. Am. Soc. Inf. Sci. 48, 963.doi:10.1002/(SICI)1097-4571(199710)48:10<963::AID-ASI15>3.0. $\mathrm{CO} ; 2-\mathrm{W}$

Griffith, B. C., Small, H., Stonehill, J. A., and Dey, S. (1974). The structure of scientific literatures II: the macro and micro-structure of science. Sci. Stud. 4, 339-365. doi:10.1177/030631277400400402

Klavans, R., and Boyack, K. W. (2017). Which type of citation analysis generates the most accurate taxonomy of scientific and technical knowledge? J. Assoc. Inf. Sci. Technol. 68, 984-998. doi:10.1002/asi.23734

Lederberg, J. (1964). Preface to the Genetics Citation Index. Philadelphia, PA: Institute for Scientific Information. Available at: http://garfield.library.upenn. edu/essays/v2p189y1974-76.pdf

Lederberg, J. (2000). "How the science citation index got started," in Web of Knowledge: A Festschrift in Honor of Eugene Garfield, eds B. Cronin and H. Atkins (Medford, NJ: Information Today, Inc.), 25-64.

Marschakova, I. V. (1973). System of document connections based on references. Sci. Tech. Inf. Ser. VINITI 5, 3-8. 
Moravcsik, M. J., and Murugesan, P. (1975). Some results on the function and quality of citations. Soc. Stud. Sci. 5, 86-92. doi:10.1177/030631277500500106

Small, H. (1973). Co-citation in the scientific literature: a new measure of the relationship between two documents. J. Am. Soc. Inf. Sci. 24, 265-269. doi:10.1002/ asi.4630240406

Small, H. (1982). Citation context analysis. Prog. Commun. Sci. 3, 287-310.

Small, H. (1999). A passage through science: crossing disciplinary boundaries. Libr. Trends 48, 72-108.

Small, H. (2003). Paradigms, citations and maps of science: a personal history. J. Am. Soc. Inf. Sci. Technol. 54, 394-399. doi:10.1002/asi.10225

Small, H. (2010). Maps of science as interdisciplinary discourse: co-citing contexts and the role of analogy. Scientometrics 83, 835-849. doi:10.1007/ s11192-009-0121-z

Small, H., and Griffith, B. C. (1974). The structure of scientific literatures I: identifying and graphing specialties. Sci. Stud. 4, 17-40. doi:10.1177/ 030631277400400102

Teufel, S., Siddharthan, A., and Tidhar, D. (2006). "Automatic classification of citation functions," in EMNLP'06: Proceedings of the 2006 Conference on Empirical Methods in Natural Language Processing, Association for Computational Linguistics, Sydney.
Thackray, A., and Brock, D. C. (2000). "Eugene Garfield: history, scientific information, and chemical endeavor," in Web of Knowledge: A Festschrift in Honor of Eugene Garfield, eds B. Cronin and H. Atkins (Medford, NJ: Information Today, Inc.), 11-23.

Wade, N. (1975). Citation analysis: a new tool for science administrators. Science 188, 429-432. doi:10.1126/science.188.4187.429

Wells, H. G. (1938). World Brain. New York: Doubleday Doran.

Wouters, P. (1999). The Citation Culture. Ph.D. dissertation, University of Amsterdam, Amsterdam. Available at: http://garfield.library.upenn.edu/ wouters/wouters.pdf

Conflict of Interest Statement: HS was employed by the company SciTech Strategies, Inc.

Copyright (c) 2018 Small. This is an open-access article distributed under the terms of the Creative Commons Attribution License (CC BY). The use, distribution or reproduction in other forums is permitted, provided the original author(s) and the copyright owner are credited and that the original publication in this journal is cited, in accordance with accepted academic practice. No use, distribution or reproduction is permitted which does not comply with these terms. 